\title{
Searching to combine technologies for safer food attainment
}

\author{
Combinando tecnologias na busca de maior segurança para os alimentos
}
Lucilla Imbroinise Azeredo CARUSO ${ }^{1 *}$, Mauro Carlos Lopes SOUZA², Ana Luzia Lauria FILGUEIRAS Sheila Silva DUQUE 3 , Wagner Thadeu ESTEVES ${ }^{3}$, Jaqueline Dark THOMÉ ${ }^{3}$

\begin{abstract}
Campylobacteriosis is an infection frequently acquired through the consumption of animal origin products. Chicken can be considered the main responsible cause in the transmission chain of this disease. Ionizing radiation was used to verify the reduction of the microbiological load of Campylobacter jejuni present in chicken liver, which, in natura, can present contamination in up to $100 \%$ of the cases. The doses of irradiation used were: $0.20 \mathrm{kGy}, 0.27 \mathrm{kGy}, 0.30 \mathrm{kGy}$ and $0.35 \mathrm{kGy}$. The samples of chicken liver were acquired in aviaries, local supermarkets and large chain supermarkets. The samples were analyzed for Campylobacter at FIOCRUZ. Irradiation was performed at COPPE/UFRJ, using a Gamma Cell Irradiator with a ${ }^{60} \mathrm{Co}$ gamma source. Only the frozen sample acquired at the local supermarket did not contain the bacterium. Campylobacter sp. was present in all other samples, even when using procedures and technologies that aimed at the impediment of the presence of this bacterium in food and, consequently, at the protection of human health. On the whole, the results were satisfactory; nevertheless, it is known that the bacterial growth conditions required by this bacterium are uncommon when compared to other enteropathogenic bacteria. Keywords: food infection; ionizing radiation; campilobacteriosis.
\end{abstract}

\section{Resumo}

A campilobacteriose é uma infecção frequentemente adquirida pelo consumo de produtos de origem animal. O frango é o principal responsável na cadeia de transmissão da enfermidade. A radiação ionizante foi utilizada para verificar a redução da carga bacteriológica de Campylobacter jejuni presente em fígados de frango, que podem apresentar, in natura, contaminação em até 100\% dos casos. As doses de irradiação utilizadas foram 0,20 kGy, 0,27 kGy, 0,30 kGy e 0,35 kGy, sendo as amostras adquiridas em aviário, supermercado de bairro, supermercado popular e supermercado de grande porte. O processamento das amostras foi feito no Setor de Campylobacter, FIOCRUZ, e as irradiações feitas na COPPE na UFRJ, com irradiador gama provido de fonte de Cobalto 60. Somente a amostra congelada, adquirida em supermercado de bairro, não continha a bactéria. Em todas as outras amostras, pôde-se observar a presença de Campylobacter sp., mesmo quando usados procedimentos e tecnologias que visam impedir sua presença no alimento e, consequentemente, proteger a saúde humana. Alguns resultados se apresentaram abaixo do esperado, porém é sabido que as condições de crescimento exigidas por esta bactéria são incomuns quando comparadas às de outros enteropatógenos.

Palavras-chave: infecção alimentar; radiação ionizante; campilobacteriose.

\section{Introduction}

Irradiation is a physical process of treatment that consists in submitting foods, already packed or in bulk, to controlled doses of ionizing radiation. It is a safe procedure, innocuous to the human health, where the radiated foods do not enter in contact with the irradiation source and, therefore, do not become radioactive. Any food can be radiated, as long as the minimum and maximum limits of applied dosage are observed. The minimum doses must be enough to reach the intended purpose and the maximum doses must be low enough not to compromise the functional properties and/or sensorial attributes of the food (ORNELLAS et al., 2006).

The products of animal origin must be in accordance with the norms of food security and the requirements for safe products are intensified in developed countries, where illnesses of alimentary origin are detected in more efficient ways, thus, extending the constant search for food free of potentially pathogenic microorganisms (ROSSI; SONCINI; ANTUNES, 2006).

Despite the Brazilian sanitary control in relation to commercialized foods, there are pathogens that need more comprehensive and constant studies, mainly those with zoonotic potential (ROSSI; SONCINI; ANTUNES, 2006), such as Campylobacter. Important neurological syndromes are associated to previous bacterial infection, such as Güillain-Barré syndrome, which is an acute feverish polyneuritis that causes weakness and/or paralysis; and Reiter syndrome, which causes

\footnotetext{
Received 25/5/2009

Accepted 31/10/2009 (004203)

Universidade Federal Rural do Rio de Janeiro - UFRRJ, Food Irradiation, Universidade Federal Fluminense - UFF, Rua Vital Brasil Filho, 64, Vital Brasil, CEP 24230-340,

Niteroi - RJ, Brasil, E-mail: lucillaia@hotmail.com

2 Laboratório de Instrumentação Nuclear - LIN, Instituto Alberto Luiz Coimbra de Pós-graduação e Pesquisa de Engenharia - COPPE,

Universidade Federal do Rio de Janeiro - UFRJ

${ }^{3}$ Instituto Oswaldo Cruz-IOC, Fundação Oswaldo Cruz - FIOCRUZ

${ }^{*}$ Corresponding author
} 
arthritis and can be followed by conjunctivitis and uveitis, leading to blindness. Both syndromes start to appear two weeks, on average, after the development of the intestinal infection caused by Campylobacter jejuni.

In developed countries Campylobacter jejuni was pointed as the most common cause of diarrhea in children, and the primary cause of enteritis in industrialized regions of the U.S., studies have shown more than two million cases per year, that is, two times more frequent than infections caused by Salmonella, having easily surpassed infections caused by Shigella. This has currently made Campylobacter to be recognized as the most important enteropathogenic bacterium (SCARCELLI et al., 2001), though presenting very low infection doses, with approximately 500 cells being necessary for the occurrence of the infection (SILVA; AMSTALDEN, 1997).

Inquired epidemiologists have demonstrated a significant correlation between the manipulation and consumption of chicken to the occurrence of Campylobacter infections. During the slaughter stage, with the manipulation and processing, chicken can be in contact with diverse species of pathogenic microorganisms, among them, Campylobacter jejuni, a microorganism present in the intestinal treatment of birds in an admittedly raised number. In most cases, the chicken infected by Campylobacter sp. do not present clinical signs, but its meat and viscera may get in contact with the feces of these animals, in the event of leakage of intestinal content.

The liver, for example, is a susceptive agent of Campylobacter jejuni infection, not only when the extravasations of the intestinal content occur during slaughtering, but also through the reflux of these microorganisms to the great hepatics vases that are connected to the thin intestine, thick intestine and stomach of birds (GETTY, 1986). Some authors point out that the chicken liver can be $100 \%$ contaminated by Campylobacter, therefore, becoming a cause of concern and a purpose of the study in question (GONÇALVES; MAIA, 2002).

Since ionizing radiation is effective to eliminate the microbial load of Campylobacter present in chicken livers, this would be another technology associated with the conventional ones already implemented to prevent this bacterium from getting in contact with humans.

\section{Materials and methods}

The samples of chicken liver were acquired in different places, in a total of four sampling points. The first sample of liver was acquired in an aviary; the second, in a local supermarket; the third, in a popular supermarket; and, the last, in a large chain supermarket, which are considered to hold high quality standards in Rio de Janeiro. All samples were congealed and packed in the way they would be commercialized and they were defrosted before being manipulated, except the one from the aviary, which was acquired cool.

The research emphasized the effect of the irradiation on the inactivation of Campylobacter jejuni, but alterations were not submitted to sensorial testing, what would require complementary studies.

According to Molins (2004), the D10 doses in Broth BHI culture medium at $0{ }^{\circ} \mathrm{C}-5^{\circ} \mathrm{C}$ temperature conditions for
Campylobacter jejuni is of $0.27 \mathrm{kGy}$, that is, the dose necessary to eliminate $90 \%$ of the present bacterial population. Using as parameter the D10 dose equivalent to $0.27 \mathrm{kGy}$, four doses of ionizing radiation; one smaller than the D10 dose $(0,20 \mathrm{kGy})$; the D10 dose itself $(0,27 \mathrm{kGy})$; and two others greater than the D10 dose $(0,30 \mathrm{kGy}$ and $0,35 \mathrm{kGy})$; were adopted for this research. The irradiation was performed at the Cobalt $\mathrm{Co}_{60}$ irradiation source, gamma ray emitter, for research means, located in the Laboratory of Nuclear Instrumentation at COPPE, Federal University of Rio de Janeiro (UFRJ).

The microbiological analyses of the samples were carried out in the sector of Campylobacter of the Laboratory of Bacterial Zoonosis at 'Oswaldo Cruz' Institute, FIOCRUZ/Rio de Janeiro. Contamination with ATCC 33560 functioned as a certification of the contamination of the samples, so that the effect of the ionizing radiation on Campylobacter jejuni could be observed, however, samples previously contaminated at the origin had to be taken in consideration and the analyses were controlled (not radiated). Campylobacter jejuni ATCC 33560 is the standard sample of the species used in in vitro contaminations. For the research, Brucella Broth was used as culture medium, obeying turbid level of 3.0 on the Mac Farland scale, and the samples remained immersed for 30 minutes.

For each sampling, 10 centrifugal machine tubes with $50.0 \mathrm{~mL}$ capacity, were identified and divided into two groups of 5 tubes each, they contained $5.0 \mathrm{~g}$ of liver each, being five tubes with chicken liver in natura and five tubes with chicken liver contaminated in vitro, as shown in the illustrative scheme below.

All tubes (except those that were not radiated, corresponding to the controlled samples) were taken to the LIN/COPPE laboratory in order to be submitted to the same ambient conditions. They were kept cooled and conditioned in thermal boxes with ice during the transport until the irradiator and back to the laboratory.

After radiated, the samples were brought back to the Laboratory of Bacterial Zoonoses, where they were macerated and streaked in plates - containing Columbia Agar activated coal $(0.4 \mathrm{~g} \%)$ with $5 \mathrm{~mL}$ of oxygen- reducer solution (FBP) and $0.5 \mathrm{~mL}$ of an antibiotic mixture, added to become a propitious way of culture to Campylobacter growth, which is sufficiently sensitive to oxygen (FILGUEIRAS; HOFER, 1989). The antibiotic mixture was added to prevent the growth of other bacteria and yeasts that could compete with Campylobacter in the culture medium.

The plating was performed using a bacteriological loop and each sample had a corresponding plate. These plates, duly streaked, were placed in $3.5 \mathrm{~L}$ jars and incubated in microaerophilic atmosphere, which was generated by the passivation of copper (FILGUEIRAS; HOFER, 1989) at $37^{\circ} \mathrm{C}$ for 48 hours.

Their growth was further analyzed in a macroscopic and microscopic way. During the macroscopic monitoring, the growth of the plates was analyzed as per the morphology of the colonies (raised, growing along the streaking and often shining). For the microscopic analysis, one drop of saline solution was placed on each slide labeled according to the plate from 
which the material was removed and, with the help of a sterile bacteriological loop, the bacteria previously grown were scraped and the smearing was performed directly on the microscopic slide. Each slide was stained through Gram's Method and analyzed at the optical microscope using $100 \mathrm{X}$ objective lens.

Brucella broth was added to the same tube where the samples were included, after the removal of the streaking portion. It increased the volume of the tube up to $50.0 \mathrm{~mL}$, followed by the processes of homogenization, packaging in jars and incubation in microaerophilic atmosphere at $37^{\circ} \mathrm{C}$ for 48 hours. Brucella broth was added aiming to stimulate the growth of Campylobacter by using the enrichment medium.

After the incubation period of 48 hours, the metallic jar with tubes was opened, and $0.1 \mathrm{~mL}$ of the broth presenting bacterial growth was pipetted from each tube. This portion was placed on the plates identified according to each tube and a new streaking was performed. The streaking plates were reincubated in microaerophilic environment at $37^{\circ} \mathrm{C}$ for 48 hours.

The macroscopic and microscopic analyses of the plates were performed.

The analysis of the in natura non-irradiated control sample was performed after removing the product packaging, due to the need to examine the presence of Campylobacter sp. in chicken liver samples prior to the contamination of those in vitro.

Five $50.0 \mathrm{~mL}$ centrifuge tubes were separated and identified. Each tube had $5.0 \mathrm{~g}$ of chicken liver, as per the following: five $5.0 \mathrm{~g}$ samples of (non-contaminated) in natura chicken liver were separated, being one (non-irradiated) control sample and the other four $5.0 \mathrm{~g}$ portions irradiated with the four different doses described above.

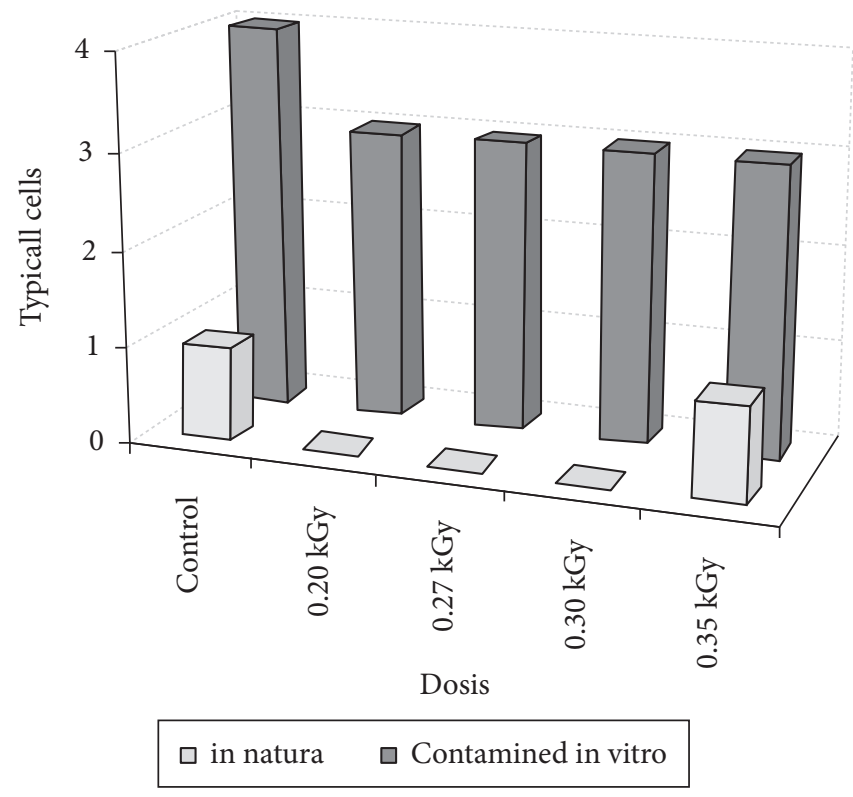

Figure 1. Contaminated samples in vitro: control not irradiated, radiated with $0.20 \mathrm{kGy}$, radiated with $0.27 \mathrm{kGy}$, radiated with $0.30 \mathrm{kGy}$ and radiated with $0.35 \mathrm{kGy}$.
After irradiation, the in natura samples returned to the Laboratory of Bacterial Zoonoses and the streaking procedures were the same as described for in vitro contaminated samples. The corresponding plates were properly stored in jars and incubated in microaerophilic atmosphere at $37^{\circ} \mathrm{C}$ for 48 hours.

Brucella broth was added to the tube containing the samples, according to the procedure for in vitro contaminated samples. The addition of Brucella broth as an enrichment medium was performed to stimulate the growth of Campylobacter sp., and to analyze the feasibility of bacteria proliferation even after irradiation. The tubes containing the enrichment medium were incubated in microaerophilic conditions at $37^{\circ} \mathrm{C}$ for 48 hours. After the incubation period, the plating was performed and reanalyzed.

\section{Results and discussion}

According to Silva and Amstalden (1997), a low amount of cells is usually found while detecting Campylobacter in food, especially if the food is frozen. As previously mentioned, the problem is that the infective dose of Campylobacter is actually quite low and this bacterium is commonly found in chicken liver. According to some authors, the bacterium is difficult to grow at temperatures below $30^{\circ} \mathrm{C}$. Nevertheless, it survives better at cold temperatures rather than at temperatures around $25^{\circ} \mathrm{C}$. In order to develop bacterial growth, it is necessary to use selective enrichment and incubation in microaerophilic atmosphere (85\% $\mathrm{N}_{2}, 10 \% \mathrm{CO}_{2}$ and $5 \% \mathrm{O}_{2}$ ) (FILGUEIRAS; HOFER, 1989), which was followed at the research methodology.

Although there are studies indicating that freezing reduces the number of Campylobacter bacteria present in raw meat, due to their low temperature sensitivity (SILVA; AMSTALDEN, 1997), some authors found no significant difference in the

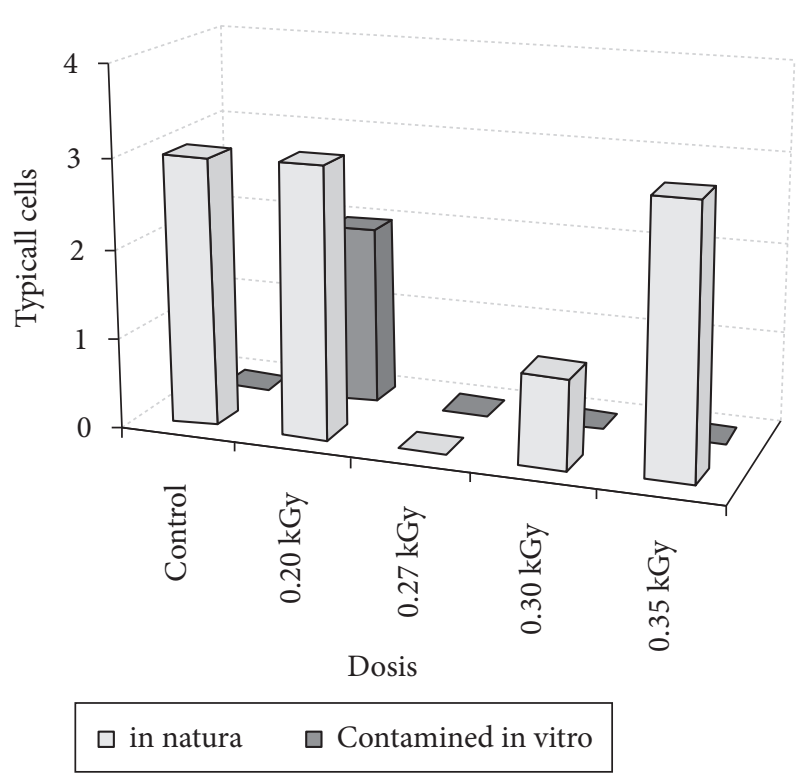

Figure 2. Samples in natura: control not radiated, irradiated with $0.20 \mathrm{kGy}$, radiated with $0.27 \mathrm{kGy}$, radiated with $0.30 \mathrm{kGy}$ and radiated with $0.35 \mathrm{kGy}$. 
incidence of Campylobacter jejuni between fresh and frozen samples, even after selective enrichment. This proves that this microorganism is able to survive at the cooling and freezing conditions previously tested (MAZIERO, 2007).

Silva and Amstalden (1997) stated that Campylobacter jejuni, Campylobacter lari, and Campylobacter coli are the most common species that cause acute gastroenteritis transmitted by food and are able to survive better at refrigeration temperatures than at temperatures around $25^{\circ} \mathrm{C}$. However, they indicated that these bacteria were extremely sensitive to the oxygen concentration in the air and to the freezing temperature, which was not observed in this study, due to their growth and full microbial proliferation of bacteria in frozen samples.

During the standardization phase of the contamination experiment of chicken liver in vitro by Campylobacter jejuni ATCC 33560, it could be observed that both control samples, the one which was purchased cold in an aviary and the other purchased frozen in a popular supermarket, were found to be positive for Campylobacter sp., what proved the bacterium resistance to low temperatures and the results found by Maziero (2007). Although there were found up to $25 \%$ of cells by microscope field, these cells were under their normal shape and in full microbial proliferation conditions.

From the results presented for the samples that were immersed and removed immediately from the contaminated Brucella broth $\left(\mathrm{T}_{0}\right)$, it was concluded that a quick contact is enough to contaminate the chicken liver with Campylobacter jejuni. We believe that the liver is frequently contaminated due to its friable muscles, which can be easily penetrated by the bacterium. The analyzed slides apparently presented the field with a lot more than 500 cells (infectious dose of Campylobacter).

The production flow intensity in businesses attested by the Federal Inspection Service in Brazil, destined for the domestic and foreign markets, is about 380,000 birds slaughtered per day (CALIXTO, 2005). Production increase and market demand led to the replacement of the workmanship by machinery. Currently, disembowelment and evisceration machines are used at the evisceration line of birds. This machinery presents a large and critical control and inspection point. The mechanical eviscerator has a kind of shovel that goes inside the bird and pulls its entrails out. As the bird comes off the machine, a hook goes up, leaving a hole, and bringing up the entrails. Due to the production volume, no one knows exactly how many birds end up with leakage of intestinal content in this phase; but if the contact is enough to contaminate, this step becomes an important critical control point for contamination.

In the standardization of the experiment and verification of the time required for in vitro contamination of chicken liver by Campylobacter jejuni ATCC, five different exposure times were tested $\left(\mathrm{T}_{0}, \mathrm{~T}_{30}, \mathrm{~T}_{60}, \mathrm{~T}_{90}\right.$ and $\left.\mathrm{T}_{120}\right)$ with the following results: for the exposure time $\mathrm{T}_{30}$, it was seen a higher number of typical cells, when compared to $\mathrm{T}_{0}$. The slide had typical " $\mathrm{S}$ " or gullshaped typical cells. For the exposure time $\mathrm{T}_{60}$, it was observed that, although they had a large number of typical cells, many of these cells began to present a coccoid form, indicating the lack of feasibility. The exposure time $\mathrm{T}_{90}$ indicated stability in relation to T60, for the similarity and characteristics of the cells found. For the exposure time $\mathrm{T}_{120}$, it was observed that, although there was a large amount of typical cells, a higher number of cells, compared to $\mathrm{T}_{60}$, presented the coccoid form and the others were still in pre-degenerative state.

Pilot experiments were needed to determine the best exposure time for contamination by Campylobacter jejuni ATCC in chicken liver. It was concluded that the time would be 30 minutes, because after this period, the cells began to present the coccoid form, i.e. they presented degenerative morphologic alteration. This exposure time was considered ideal for the presence of a higher number of typical cells at full capacity for microbial growth.

After discussing the contamination of meat and their viscera during processing, through the leakage of intestinal content, it was concluded that this may not be the only source of contamination. In an article on sources of contamination of chicken meat, the presence of the bacterium was detected in cloacal swab, carcass cleaning water, as well as in cages and feathers - indicating that these birds may be a source of contamination by Campylobacter sp., even before they are slaughtered (BATISTA; AIDDO; FRANCHIN, 2005). According to another study on the analysis of water in various stages of poultry processing, $48 \%$ of 288 collected samples tested positive for Campylobacter jejuni (CORTEZ et al., 2006), what ratified the abovementioned results. Specially, Campylobacter jejuni is a microorganism of greater significance for public health, because it is the main cause of human diarrhea and may lead to liquid or bloody diarrhea (BUTZLER; OOSTEROM, 1991).

Regarding the reduction of the intestinal tract of birds, which would be another alternative to avoid contamination in case of intestinal rupture, one of the recommendations of SDA's Ordinance no. 210 (Nov. 10, 1998) would be a complete fast - which must be mandatorily done at the farms - from 10 to 12 hours before the slaughtering (BRASIL, 1998). Another procedure is the supply of clean and chlorinated water to farm animals, because studies show that one of the ways of contamination of farm chicken by Campylobacter jejuni is through contaminated water supply (GAMA, 2007). The water chlorination is effective in the elimination of this bacterium (CARVALHO et al., 2001). In fact, chickens drink two to three times more water than chicken feed and many diseases may be transmitted to birds through the water, either through contamination of excretions and/or feces of sick birds, or through the use of water previously contaminated by potentially pathogenic agents derived from other animal species and/or the human beings. The microbiological quality of the water greatly interferes in poultry production; nevertheless, it is often overlooked by producers and technicians. Campylobacter is frequently found in the water supplied to birds and survive well in the formation of biofilms in the water surface in aviaries (GAMA, 2007).

Campylobacter sp. probably grows in the plantation and it is not acquired through vertical transmission. However, this issue is a matter of controversy and discussion among authors worldwide, due to the fact that the epidemiology of this disease has not been fully unveiled (ROSSI; SONCINI; 
ANTUNES, 2006).In order to provide a plantation free of Campylobacter sp., there must be an associated work with engineers, microbiologists and veterinarians. In spite of the high cost to arrange this joint work, it might be worth it, considering the expenses such disease brings on (SKIRROW, 1990b). In a recent study on vertical transmission of Campylobacter sp., the bacterium was not found in fresh, infertile and embryonated eggs, eggs and organs of chicks, neither in the incubator environment. However, the study does not state the absence of vertical transmission of the bacterium, suggesting a new study on molecular techniques (ROSSI; SONCINI; ANTUNES, 2006).

The experiment itself was based on qualitative analysis, i.e. the analysis of the presence or absence of bacteria in the sample. The amount of cells included in each sample was compared. Only the frozen sample purchased at the popular supermarket did not contain the bacteria. In all other samples, either frozen or cooled, the presence of Campylobacter sp. was observed. All samples were subjected to procedures or technologies aimed at preventing this bacterium in food and, therefore, protecting human health; except the fresh sample purchased in aviary.

When analyzing the images, it should be emphasized that the results were based on a comparison between the samples by qualitative analysis. The "X" axis (represented by the horizontal line) shows the ionizing radiation doses to which the samples were exposed. Again, the control sample was not irradiated and the radiation doses used were $0.20 \mathrm{kGy}, 0.27 \mathrm{kGy}, 0.30 \mathrm{kGy}$ and $0.35 \mathrm{kGy}$. The "Y" axis (represented by the vertical line) shows, in numbers, the presence or absence of typical cells of Campylobacter sp. The axis ranged from 0 to 4 and used the following comparison standard between the samples: 0 for the absence of typical cells, 1 for the presence of up to $25 \%$ of typical cells, 2 for the presence of $25-50 \%$ of typical cells, 3 for the presence of $50-75 \%$ of typical cells and, 4 for the presence of $75-100 \%$ typical cells per microscope field analyzed.

In the sample purchased at a high quality standard supermarket, the in natura control sample was contaminated with Campylobacter sp. The bacterium was not found in in natura samples irradiated at $0.20 \mathrm{kGy}, 0.27 \mathrm{kGy}$ and $0.30 \mathrm{kGy}$ doses, but at the highest dose of ionizing radiation, $0.35 \mathrm{kGy}$, it was again observed the presence of Campylobacter sp., as shown in Figure 1. Livers sizes were different and it was often necessary to use different livers to reach the total volume, in which case the liver sample came from different birds, although they were all packed together.

Also regarding Figure 1, it can be observed that the samples contaminated with the standard strain ATCC and irradiated (when compared to standard non-irradiated sample) had a small reduction in the number of cells, which remained constant even during dose escalation. However, at the $0.30 \mathrm{kGy}$ dose, the ATCC strain cells began to change their morphology, what could be better observed in the highest dose ( $0.35 \mathrm{kGy})$.

During streaking, using samples incubated in Brucella broth, as shown in Figure 2, it was confirmed the expectation as for the effect of enrichment medium over Campylobacter. It was observed that in natura control samples, $0.20 \mathrm{kGy}$ and $0.35 \mathrm{kGy}$ had many typical cells, while the sample exposed to $0.30 \mathrm{kGy}$ was also tested positive, but with less cells. It can be observed that, despite not having found the bacterium in streaking prior to enrichment, when there were favorable conditions for its development, the incubation in enrichment medium enabled the observation of the full capacity of the bacterium proliferation, even after irradiation ( $0.20 \mathrm{kGy}$ and $0.30 \mathrm{kGy})$. Among the in vitro contaminated samples, the only one that showed microbial growth after incubation in Brucella broth was the one exposed to $0.20 \mathrm{kGy}$ (Figure 2).

In the sample purchased at the popular supermarket (considered to have an average quality standard), the in natura control sample was contaminated with Campylobacter sp. After irradiation, the sample exposed to a $0.20 \mathrm{kGy}$ dose still contained this microorganism. But when the dose was increased, the bacterium was not found, as shown in Figure 3. At the $0.30 \mathrm{kGy}$ dose, the cells of ATCC 33560 strain began to change their morphology, what can be better observed at the highest dose $(0.35 \mathrm{kGy})$. Also regarding Figure 3, the reduction in the number of cells in the standard samples can be clearly observed, as the dose of ionizing radiation increases.

After incubation in Brucella broth, all ATCC samples showed many contaminants and many cells with morphological changes, even at lower irradiation doses. In Figure 4, Campylobacter sp. was not found in any of the in natura samples.

In the case of the control sample and the sample exposed to $0.20 \mathrm{kGy}$, which was tested positive before incubation in broth, this lack of bacteria prior to the selective enrichment could be due to the competitiveness of other microorganisms present in the samples. From the moment that these contaminants were also benefited by the conditions offered by the enrichment medium, its development ended up compromising the growth of Campylobacter cells, probably present in smaller quantities

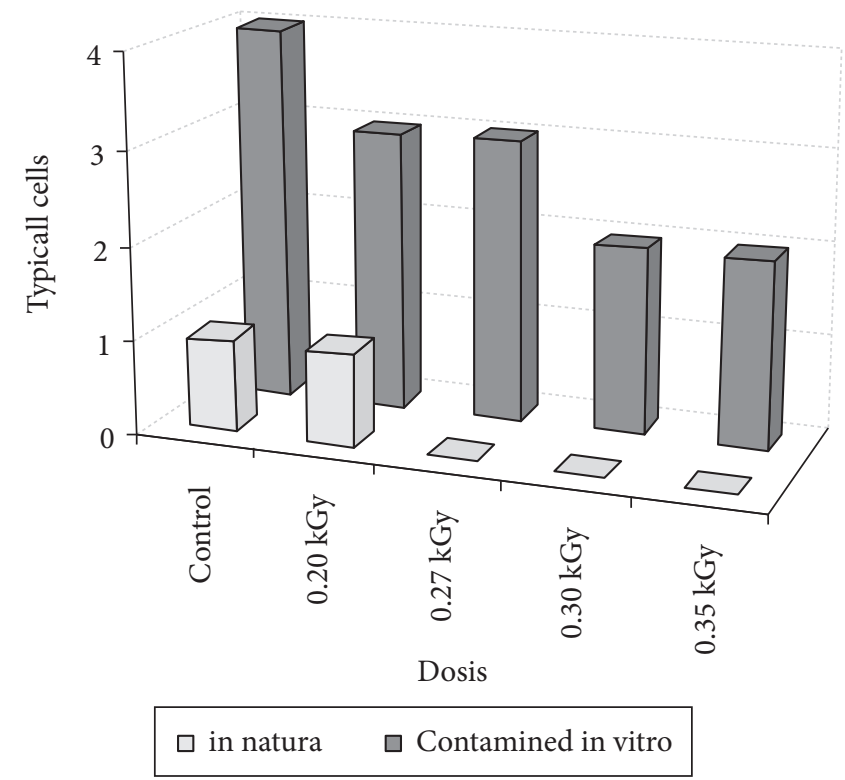

Figure 3. Streaking of the sample purchased at a popular supermarket, before incubation in Brucella Broth. 
than the other contaminants in the samples. The optimal growth time for Campylobacter sp. is 48 hours, while most of the other enteropathogens have its optimal growth time between 18 and 24 hours.

Still analyzing the results indicated in Figure 4, it is observed that the standard control samples and those irradiated at $0.20 \mathrm{kGy}$ and $0.27 \mathrm{kGy}$ remained stable compared to the results presented in the streaking performed before and after enrichment. There was microbiological growth in the sample exposed to $0.35 \mathrm{kGy}$ irradiation dose, even this being the highest dose. At $0.30 \mathrm{kGy}$ dose, no Campylobacter sp. cells were found, which can also be due to the competitive growth of bacteria and other microorganisms in the environment.

In Figure 5, it is observed that the control sample purchased at the local supermarket did not present growth of Campylobacter sp., which can be observed even after incubation in Brucella broth (Figure 6). Regarding the standard samples, there was a clear reduction in the number of cells as the ionizing radiation increased, which was also observed in Figure 5. Although Campylobacter sp. was tested negative, all samples were filled with contaminants. At the $0.35 \mathrm{kGy}$ dose, the ATCC strain cells showed changes in their morphology.

After culture in Brucella broth, the negative results in standard samples may also be due to the competitive growth of Campylobacter sp. with the contaminants (rods and yeasts) present in the medium.

In the sample purchased at an aviary (fresh sample), the in natura control sample was contaminated with Campylobacter sp. In addition, all other in natura samples were filled with contaminants. The lower dose $(0.20 \mathrm{kGy})$ and the $0.27 \mathrm{kGy}$ dose maintained their stability in relation to the number of cells they had, even before irradiation. At the $0.35 \mathrm{kGy}$ dose, some cells of

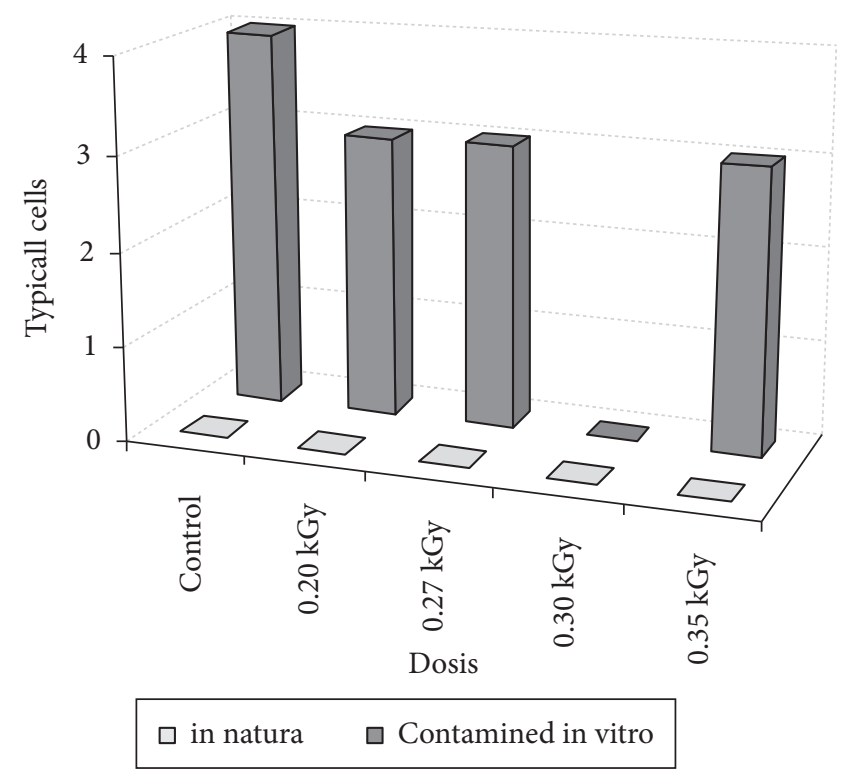

Figure 4. Streaking of the sample purchased at a popular supermarket, before incubation in Brucella Broth.
ATCC strain showed changes in their morphology. When exposed to the two higher doses $(0.30$ and $0.35 \mathrm{kGy})$, the bacterium was not found in the samples before incubation in Brucella broth, as it can be observed in Figure 7.

On the other hand, at the $0.30 \mathrm{kGy}$ dose, the bacterial growth presented after incubation in Brucella broth, shown in Figure 8, was very high, what proves the feasibility of microbial proliferation of Campylobacter sp. even before irradiation.

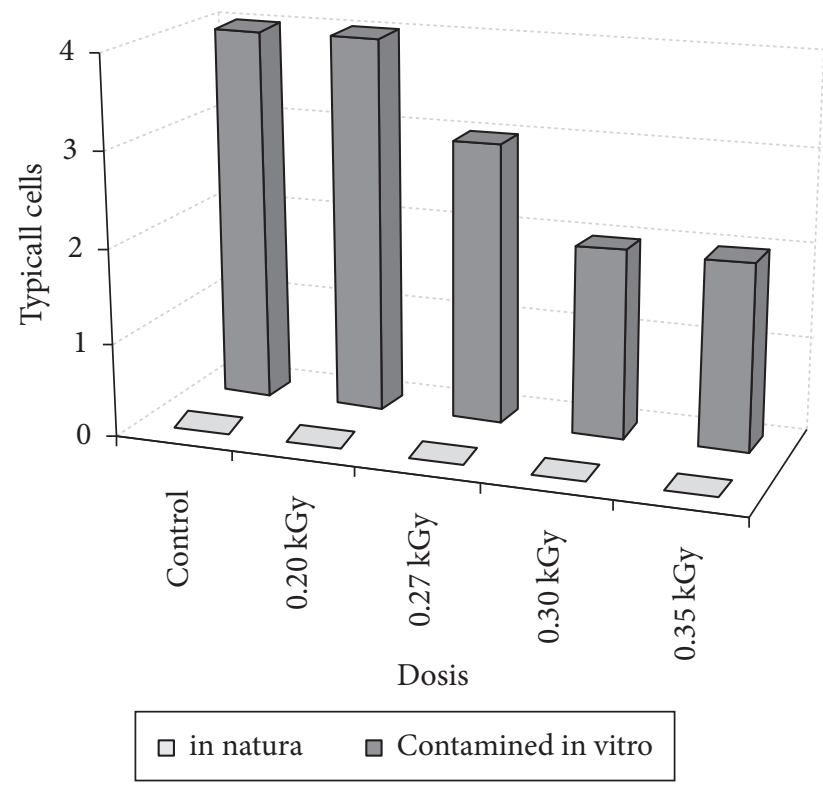

Figure 5. Streaking of the sample purchased at a local supermarket, before incubation in Brucella Broth.

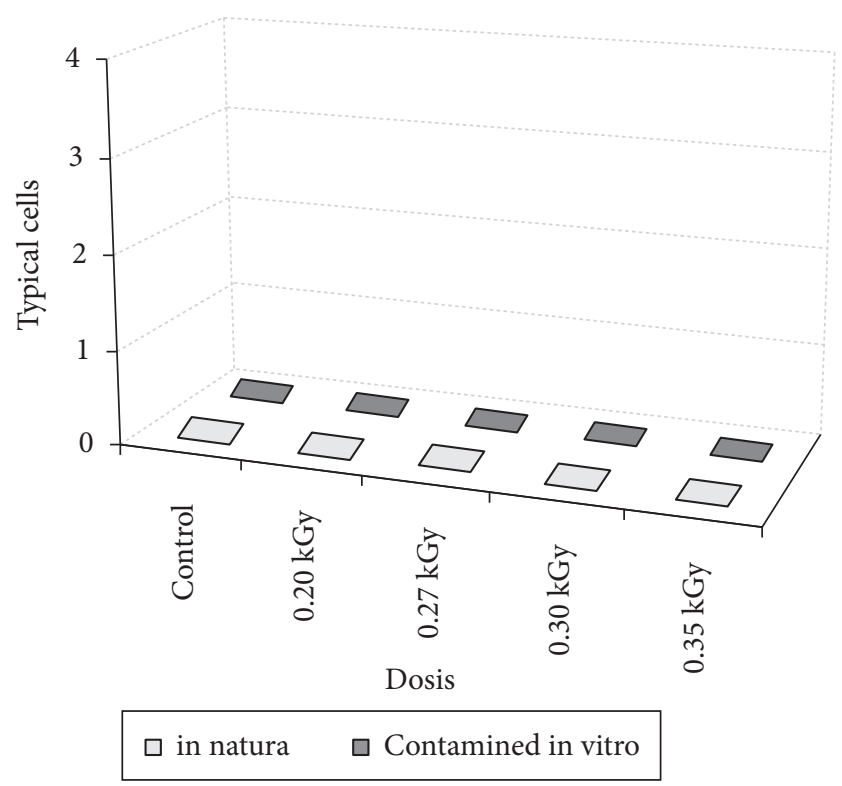

Figure 6. Streaking of the sample purchased at a local supermarket, after incubation in Brucella Broth. 


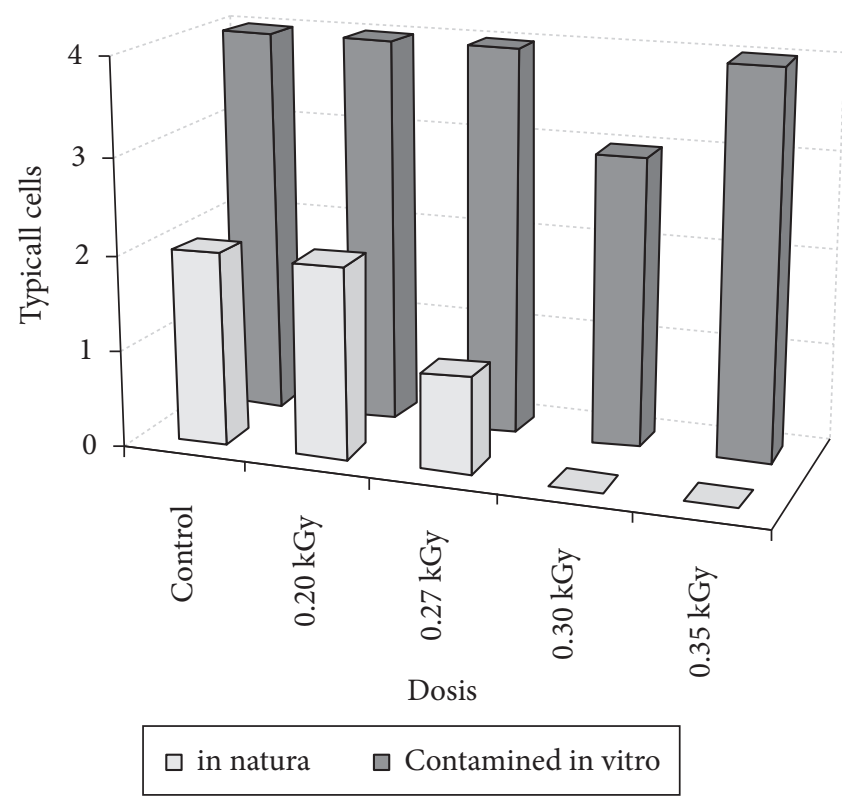

Figure 7. Streaking of the sample purchased at an aviary, before incubation in Brucella Broth.

The standard samples did not respond to the expectations, even at the highest doses of ionizing radiation, and had a huge growth, despite their morphological changes.

Many studies have proved the effectiveness of irradiation as a process for inactivation of Campylobacter jejuni, but contradictions still exist regarding the dose required to inactivate $90 \%$ of the population of microorganisms present in the samples (dose D10); and these doses have many variables. These variables depend on the species (beef, pork, fish, rabbit and poultry), their type (steak, ground, whole and pieces) and even on the way these foods are being irradiated (packed, etc.). The D10 dose specific for chicken livers and inactivation of Campylobacter jejuni is still unknown.

The results from the experiment showed that when there was a small amount of cells, as in the in natura samples, the inactivation by irradiation was effective as from $0.27 \mathrm{kGy}$. However, when the amount of cells is very large, as in the contaminated samples with a number of cells higher than the infecting dose; although morphological changes were observed by ionizing radiation, Campylobacter jejuni in favorable growth conditions remained in full microbial proliferation status. In all previous studies on the efficiency of irradiation and the sensitivity of Campylobacter sp., the used doses were lower than the ones of this research.

\section{Conclusions}

There are several strategies for hygiene and sanitary control in our country in order to prevent foodborne diseases. Regarding poultry meat, viscera and their products, there is the SDA (Secretariat of Agricultural Development) Ordinance No. 210 (Nov 26, 1998) and many other studies in this field, aiming to provide safety to food products supplied to the population.

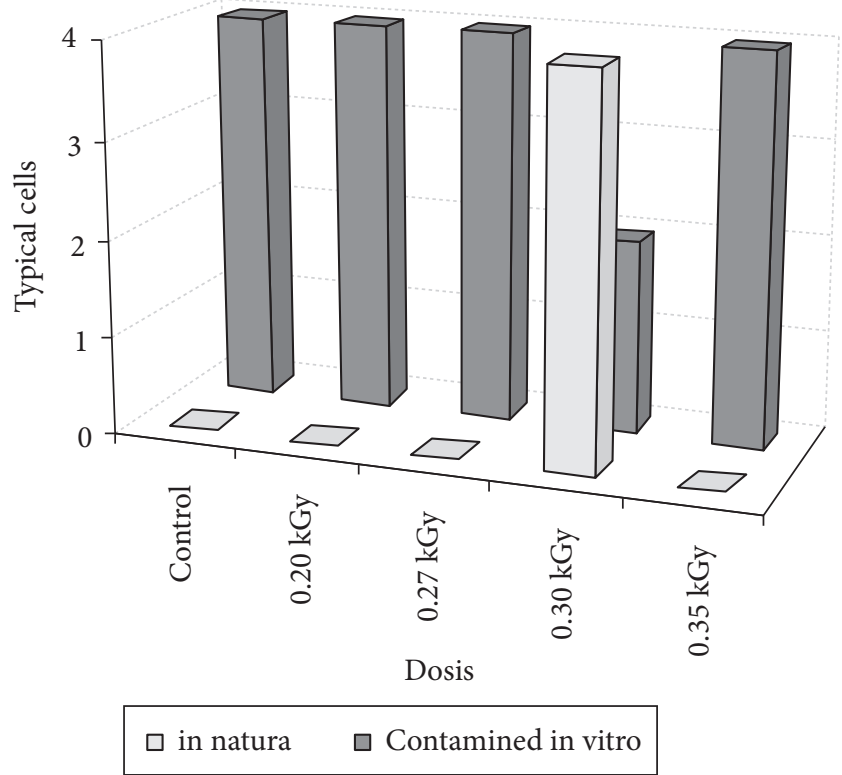

Figure 8. Streaking of the sample purchased at an aviary, after incubation in Brucella Broth.

In the case of campylobacteriosis, many efforts have been made to reduce the presence of this bacterium in poultry meat and viscera. Yet, the results are still very poor and the bacterium is often found in this type of food.

The production of Campylobacter-free chicken meat is not feasible yet. However, a considerable progress may be achieved through the action of the government and the poultry industry (SKIRROW, 1990a), since the control of campylobacteriosis is related to the control at the processing of these birds.

The decrease of infection in humans might be achieved by providing the community with information on this subject and good hygiene practices during preparation and processing of food, since most illnesses caused by Campylobacter sp. are due to the handling or ingesting of contaminated chicken meat in raw or barely cooked state. The simple handling of contaminated chicken meat before cooking is the major cause of contamination, mainly through chopping boards, containers, utensils used in the preparation and cross-contamination with foods that are eaten in raw state (BUTZLER; OOSTEROM, 1991). So, the most effective alternative to control this disease is still the proper cooking and the awareness while preparing and handling the meat, but all this will only be effective if these actions are also performed during the processing and breeding procedures of these animals (SKIRROW, 1990b).

The procedures and technologies are not enough to prevent the bacterium from reaching out the consumers' food, which could bring damages to their health. Therefore, a connection between technology and the provision of a better sanitary control is required.

The contradictions between the existing studies and the results obtained show the need for a deeper understanding, 
in order to know the actual behavior of Campylobacter sp. after being exposed to ionizing radiation. This is due to the fact that, even at higher doses, the bacterium remains in its full proliferation capacity after the selective enrichment was performed.

Thus, it is proposed for further papers, a study on the doses of ionizing radiation, with quantitative analysis of cells, in order to obtain the D10 specific dose for chicken livers during the inactivation of Campylobacter jejuni. Consequently, the survival strategies of this bacterium in natural environment could be better understood, since it is known that the growth conditions required by Campylobacter are unusual compared to other pathogenic bacteria.

\section{Acknowledgements}

The authors are grateful to the following institutions: 'Universidade Federal Fluminense' (Fluminense Federal University); 'Fundação Oswaldo Cruz' (Oswaldo Cruz Foundation); 'Laboratório de Instrumentação Nuclear COPPE/UFRJ' (Laboratory of Nuclear Instrumentation COPPE/UFRJ).

\section{References}

BATISTA, C. R. V.; AIDOO, K. E.; FRANCHIN P. R. Sources of poultry meat contamination with termophilic Campylobacter before slaughter. Brasilian Journal of Microbiology: Revista da Sociedade Brasileira de Microbiologia, v. 36, p. 157-162, 2005. http://dx.doi. org/10.1590/S1517-83822005000200011

BRASIL. Ministério da Agricultura, Pecuária a Abastecimento. Portaria número 210, de 10 de novembro de 1998. Aprova o regulamento técnico da inspeção tecnológica e higiênico-sanitária da carne de aves. Diário Oficial da República Federativa do Brasil, Secretaria de Defesa Agropecuária, Brasília, DF. 26 nov. 1998. Seção 1.

BUTZLER, J. P.; OOSTEROM J. Campylobacter pathogenicity and significance in foods. International Journal of Food Microbiology, v. 12, p. 1-8, 1991. http://dx.doi.org/10.1016/0168-1605(91)90043-O

CALIXTO, F. A. A. Relatório final. 2005. 141 f. Relatório de Conclusão de Curso (Graduação em Medicina Veterinária)-Faculdade de Veterinária, Universidade Federal Fluminense, Niterói, 2005.

CARVALHO, A. C. F. B. et al. Campylobacter em granja avícola. Revista Portuguesa de Ciências Veterinárias, v. 96, n. 540, p. 191-195, 2001.

CORTEZ, A. L. L. et al. Survey of chicken abattoir for the presence of Campylobacter jejuni e Campylobacter coli. Revista do Instituto de Medicina Tropical, v. 48, n. 6, p. 307-310, 2006. http://dx.doi. org/10.1590/S0036-46652006000600001

FILGUEIRAS, A. L. L.; HOFER, E. Ocorrência de Campylobacter termofílico em diferentes pontos de uma estação de tratamento de esgotos na cidade do Rio de Janeiro, RJ. Revista de Microbiologia, v. 20, n. 3, p. 303-308, 1989.

GAMA, N. M. S. Q. Qualidade química e bacteriológica utilizada na dessedentação de aves. In: SIMPÓSIO BRASIL SUL DE AVICUlTURA, 8., 2007, Chapecó. Anais... Chapecó, 2007.

GETTY, D. V. M. R. Anatomia dos animais domésticos. 5. ed. Rio de janeiro: Guanabara Koogan, 1986. 2000 p., 2 v.

GONÇALVES, P. M. R.; MAIA, R. Avaliação dos meios de enriquecimento para a pesquisa de Campylobacter jejuni em produtos de origem animal. Revista Higiene Alimentar, v. 16, n. 98, p. 79-84, 2002.

MAZIERO, M. T. Contaminação de carcaças de frango por Campylobacter jejuni antes e após resfriamento e congelamento. 2007. 136 f. Dissertação (Mestrado em Ciências e Tecnologia de Alimentos) - Universidade Estadual de Londrina, Londrina, 2007.

MOLINS, R. A. Irradiación de Alimentos, principios y aplicaciones. Tradução Alberto Ibarz Ribas. Zaragoza, España: Ed. Acribia, 2004. 459 p. Tradução de: Food irradiation: principles and application.

ORNELLAS, C. B. D. et al. Atitude do consumidor frente à irradiação de alimentos. Ciência e Tecnologia de Alimentos, v. 26, n. 1, 2006. http://dx.doi.org/10.1590/S0101-20612006000100033

ROSSI, D. A.; SONCINI, R. A.; ANTUNES, R. C. Transmissão vertical de Campylobacter sp. em um sistema de produção avícola. 2006. 64 f. Dissertação (Mestrado em Ciências Veterinárias)-Universidade Federal de Uberlândia, Uberlândia, 2006.

SCARCELLI, E. et al. Emprego da técnica do polimorfismo de comprimento dos fragmentos de restrição (RFLP) do produto obtido pela reação da polimerase em cadeia (PCR) do gene FLA na subtipagem de amostras de Campylobacter jejuni subsp. jejuni isoladas de frangos de corte e humanos. Arquivos do Instituto Biológico, v. 70, n. 3, p. 1-5. 2001.

SKIRROW, M. B. Foodborne illness: Campylobacter. The lancet, v. 336, p. 921-923, 1990a. http://dx.doi.org/10.1016/01406736(90)92282-M

SKIRROW, M. B. Epidemiology of Campylobacter enteritis. International Journal of Food Microbiology, v. 12, p. 9-16, $1990 \mathrm{~b}$. http://dx.doi.org/10.1016/0168-1605(91)90044-P

SILVA, N.; AMSTALDEN, V. C. Detecção de Campylobacter. São Paulo: Livraria Varela, 1997. cap. 18, p. 142-148. (Manual de métodos de análise microbiológica). 